\author{
Вікторія Назаревич, \\ кандидат психологічних наук, \\ дочент кафедри вікової \\ та педагогічної психології \\ Рівненського державного \\ гуманітарного університету \\ Victoria Nazarevich, \\ PhD (Psychology), \\ Associate of the Department \\ of Age and Pedagogical Psychology \\ of «Rivne State University \\ of Humanities» \\ E-mail: nazarevich.art@gmail.com \\ ORCID 0000-0002-0111-7070 \\ Ірина Борейчук, \\ кандидат психологічних наук, \\ дочент кафедри загальної \\ психології та психодіагностики \\ Рівненського державного \\ гуманітарного університету \\ Iryna Boreychuk, \\ PhD (Psychology), \\ Associate of the Department of \\ General Psychology and \\ Psychodiagnostics of «Rivne State \\ University of Humanities» \\ E-mail: irina_boreychuck@mail.ru \\ ORCID 0000-0001-9205-5655
}

\title{
ФІЛОСОФСЬКИЙ КОМПОНЕНТ ПСИХОЛОГІЇ «ІНШОГО» В СИСТЕМІ ОСТРАКІЗАЦІЇ СЕРЕДОВИЩА
}

У статті зроблено спробу визначити філософський компонент розуміння образу «іншого» та систематизувати сочіально-психологічні, філософські уявлення про відчуження як механізм остракізації в групі. Розглянуто особливості психологічної трансформації ксенофобного реагування на «іншого» як об'єкта остракізачії. На прикладі аналізу навчального простору розкрито остракізм як акт або систему ігнорування/виключення окремих осіб та головний елемент прояву ксенофобії. Проаналізовано поняття «іншого» в системі наукових знань у рамках філософського феномену ксенофобї та визначено його як порушення гомеостазу сочіальної групи, щуо стає причиною нової атрибутивної поведінки. Здійснено спробу аналізу теоретичних моделей та особливостей реагування особистості на «іншого», таких як заперечення, незачікавленість, критика, упередження, уникнення, неприйняття, зрада, стигматизація, зневага, залишення, образа, залякування та різні дрібні образи. Досліджено систему образів з метою розкриття поняття остракізму в психологічній науці як акту або системи ігнорування, виключення окремих осіб. Показано, ше незважаючи на відсутність словесних принижень і фізичних нападів, його прояви є болючими та загрожують психологічним потребам (приналежності, почуття власноі гідності, контролю і осмисленості існування); щуо викликає різні психічні, афективні, когнітивні $i$ поведінкові реакиї. Зроблено висновки, що сприйняття/несприйняття «іншого» виступає підтрунтям суспільної ідентифікації та категоризації в рамках філософського розгляду феномену ксенофобії. Прочес трансформачії «чужого» на «іншого» передбачає пізнання та сприйняття його не тільки конкурентом і супротивником, але й партнером і співрозмовником, що є складним сочіально адаптаційним утворенням та потребує системного супроводу в суспільстві.

Ключові слова: чужий, страх, ксенофобія, остракізм, інший, самоідентифікація, відчуження, мініміф.

The authors make an attempt to determine the philosophical component of understanding the vision of «other» and systematized socio-psychological, philosophical ideas about alienation as a mechanism of ostracism in the group. In the article, it's explores the concept of «another» that serves as the basis for social identification and categorization as part of the philosophical consideration of the phenomenon of xenophobia. The authors reveals the social self-identification, which acquires the typical features of negative identification, leads to aggravation of conflicts, bullying, psychological pressure on 
the «other». The basis is polar categorization - «alien is an enemy, and» another «is the primary object of cognition». In this sense, "stranger» acts as a significant factor in the process of self-identification. But one should say that self-identification can take the form of negative identification, when the content of «his» is determined not by the reproduction of the positive features and values of his "I» or «We» but because of the denial of «someone else». As a result, an alien is identified with the enemy, which, in turn, loses the opportunity to be a constructive factor and turns into destructive force. The importance of the psychological transformation of xenophobic reaction to the "other" as an object of ostracism is argued. Ostracism is an act or system of ignoring / eliminating individuals and is a key element of manifestation of xenophobia, which the authors reveal by way of analysis of the educational space. As part of the prevention of ostracism, we anticipate that the child should be provided with the transparency of the child in the initial space, a pedagogue who includes the child in the social space, the psychologist, providing joint engagement actions, will also positively affect the general status of stress and ostracism. "Alien» to "another», which one must know and love, which can be not only a competitor and an opponent, but also a partner and interlocutor. Such a process is a complex social adaptation education and needs system support in the educational space. In the process of development of inclusive consciousness, it is important not to use the notion of «someone else», since the concept of «other» provides the possibility of knowledge and, as a consequence, the prevention of identification with the enemy, which, in turn, does not lose the opportunity to be a constructive factor and turns into the driving force of knowledge and as a consequence of adoption.

Keywords: alien, fear, xenophobia, ostracism, other, self-identification, alienation, minimyth.

Постановка проблеми. Проблематика «іншого» та «інакшого» в сучасних психолого-соціальних контекстах розглядається в працях Х. Арендт, В. Малахова, О. Фельдмана, М. Поповича, С. Пролеєва. Особливе значення для цього дослідження мав дискурс психологічних наслідків глобалізації та інтеграції в Європейський простір і одним із таких аспектів $\epsilon$ інклюзивна інтеграція дітей в умови загальноосвітнього навчального закладу. Тут важливо згадати низку плідних у методологічному плані ідей, висловлених у працях У. Бека, В. Ляха, П. Слотердайка, Є. Бистрицького, М. Михальченка, Б. Андерсона.

Аналіз останніх досліджень і публікацій з даної проблематики, який дав можливість виокремити ряд репрезентацій та трансформацій ксенофобії, спирався на доробки сучасної комунікативної філософії, передусім на праці К.-О. Апеля, Ю. Габермаса. Опис діалектики ксенофобії розглядався в неомоделях філософського сприйняття «іншості» Т. Адорно, М. Горкгаймера, Е. Фромма. Поглибленню розуміння соціальних, культурних та психологічних контекстів, у яких створюються передумови ксенофобії та стають можливими iï конструктивні трансформації в соціокультурному середовищі, сприяли праці Б. Андерсона, 3. Баумана, У. Бека, Н. Бусової, Г. Йонаса, що спонукають більш структуровано розкрити аспект «іншого» як об'єкта остракізації. Відомий німецький філософ М. Хайдеггер розглядав відчуження як внутрішню властивість, атрибут буття суспільних відносин. Тому можна припустити думку про те, що якщо в сталий навчальний колектив включається «інший», чи то дитина із особливими потребами, чи просто новий учень, це виступає порушенням гомеостазу соціальної групи та стає причиною нової атрибутивної поведінки. У конструктивних варіантах це приводить до доброзичливого та 


\section{Psychology}

позитивного сприйняття і поштовхом до знайомства, а в негативних стає основою для остракізації. Соціальна група визначає себе як ідентифіковану цілісну структуру, що піддасться загрозі при появі «іншого», якого й піддають остракізації від страху розпаду цілісності атрибутивності групи.

У феномені «ідентифікація» виділяють три пересічні області психологічної реальності. У зв'язку з цим визначають ідентифікацію як:

- процес об'єднання суб'єктом себе з іншим індивідом або групою на підставі усталення емоційного зв'язку. У результаті чого дитина діє в уявному плані, «набуваючи» ті чи інші бажані властивості об'єктів, збагачуючи образ власного «Я»;

- уявлення, бачення суб'єктом іншої людини як продовження себе самого і проекцію, наділення його своїми рисами, почуттями, бажаннями. Дана ідентифікація є механізмом прояву міжособистісних стосунків;

- механізм постановки суб'єктом себе на місце іншого. Це може проявлятися у вигляді особливого занурення, перенесення індивідом себе в поле, простір, обставини іншої людини.

Усі ці структури ідентифікації піддаються впливу внаслідок появи «іншого». На думку А. Валлон, дитина пов'язана зі світом через афективну систему, має сталий емоційний контакт та носить мімічний (наслідувальний) характер i спочатку проявляється в співучасті в генетично більш ранній формі зараження, і тільки потім 3'являється співчуття. Дитина повністю занурена в свої емоції [Абраменкова, 2000: c. 78]. Завдяки емоціям вона зливається 3 відповідними ситуаціями, тобто з людським оточенням, яке найчастіше викликає емоційні реакції. Відчужуючи себе в цих ситуаціях, дитина не здатна сприймати себе як істоту, відмінну від інших людей і від кожної окремої людини. Відчуження - переживання суб'єктом почуттів відособленості, відсторонення, самотності, відкинення, втрати «Я». Спочатку дитина навчається відрізняти себе від навколишнього світу, потім відрізняє людину від інших об'єктів, потім себе від інших людей.

Згідно 3 В. Абраменковою, здатність дитини до ідентифікаціївідчуження можна уявити двоєдиним процесом, що включає одночасно асиміляцію соціального досвіду і подальшу селекцію, відбір, прийняття або відкидання для його реалізації в практиці спілкування зі світом речей i світом людей. Тут відчуження набуває позитивного сенсу, подібно до того, який вкладається у відчуження як процес опредметнення і матеріалізації [Абраменкова, 2000: с. 91].

Важливо розуміти, що гіперболізація якоїсь однієї сторони двоєдиного процесу ідентифікації-відчуження може призвести до патологічної однобокості особистості: або до іiі повного розчинення в навколишньому, або, навпаки, до неприйняття, заперечення, «тотального відчуження», егоїзму. Ще Ю. Антонян вважав, що «відчуження - це відсутність здатності суб'єкта до ідентифікації» [Абраменкова, 2000: с. 78]. Даний факт сформував зростання дослідницького інтересу до наслідків 
неприналежності індивіда до певної групи через акти остракізму, соціальної ізоляції та неприйняття, відчуження, вигнання. Однорідні поведінкові стратегії забезпечують силу і стійкість соціуму, тому наявність іншого та чужого викликає почуття загрози і неспокою. Нездатність групи прийняти «іншого» стає причиною остракізму. Забезпечуючи своєчасний психолого-профілактичний вплив, формування толерантної свідомості в навчальному просторі та іiі екстраполяцію в самосвідомість ще в ранньому дитячому віці забезпечить соціум певними психологічними інвестиціями толерантної поведінки. Отже, вивчення даного явища в начальному середовищі постає важливою проблемою психологічного аналізу та забезпечить футуристично прогнозованими конструктивними конотаціями в майбутньому. Також варто зазначити, що актуальності вивчення остракізму надає той факт, що дане явище алгоритмічно пов'язане 3 віковою, соціальною, спеціальною психологією та розкриває й поглиблює важливі парадигми психології особистості. Інтрадисциплінарність даного явища в сучасній психологічній науці забезпечить нас більш грунтовними уявленнями про природу явища - остракізації суспільства та остракізму як психологічного критерія функціонування групи й особистості в цілому.

Формулювання цілей статmі. Основною метою статті $є$ спроба систематизувати соціально-психологічні та філософські уявлення про «іншого» як об'єкта остракізації в групі.

Формуючи завдання, варто визначити важливість факту психологічної трансформації ксенофобного реагування на іншого як об'єкта остракізації. Так, завданнями стали:

- розкрити поняття «іншого» в системі наукових знань у рамках філософського феномену ксенофобії;

- визначити теоретичні моделі та особливості реагування особистості на іншого;

- сформувати систему образів 3 метою розкриття поняття остракізму в психологічній науці.

Виклад основного матеріалу. Остракізм є механізмом виключення окремих індивідів зі спільного соціально-групового простору. Соціальне неприйняття, яким супроводжується остракізація, слугує підгрунтям порушення первинних особистісних потреб, розвитком почуття власної неповноцінності, втратою контролю та осмисленості життя особи.

Розгляд проблем, пов'язаних 3 трансформаціями ксенофобії, перетворенням іiі на ксенологічно орієнтовану програму життєтворчості, був би неможливий без праць В. Андрущенка, І. Радіонової, О. Гриви, О. Микитюка, I. Прокопенка, М. Степаненка.

Дослідниками часто вивчається вплив індивідуальних поведінкових реакцій на формування явища соціального неприйняття як одного 3 основних чинників остакізації особистості. Також важливим $є$ питання вивчення механізму зниження частоти прояву соціального вигнання індивіда в суспільстві. K. Williams досліджував роль альтернативних 


\section{Psychology}

джерел підтримки особи в сфері соціального буття. М. Тервогт і Р. Коуен розкрили особливості спілкування, відторгнення і неприйняття однолітків у дітей дошкільного і шкільного віку. Було виявлено переважну афективну реакцію, викликану остракізацією, яка проявляється в «хворобливих відчуттях» (наприклад, смуток, самотність, біль, гнів, ревнощі) [Williams, 2005: c. 49]. Прояви явища, яке вивчається, можуть приймати різні форми: незацікавленість, критика, упередження, уникнення, неприйняття, зрада, стигматизація, зневага, залишення, образа, залякування та різні дрібні образи.

Разом 3 цим, психологічно-теоретичного узагальнення потребує досвід трансформації ксенофобії в сучасних інтеркультурних контекстах, виявлення іï модифікацій у різних соціокультурних ситуаціях $\mathrm{i}$ можливостей іiі трансформацій у ксенологічні практики, бо ці аспекти все ще залишаються за межами сучасних досліджень цього феномену. Ксенофобію розглядають як антипод толерантності, як своєрідну антитолерантність / інтолерантність, що для психологічної науки $\epsilon$ системною вимогою вивчення остракізму при неприйнятті «іншого» [Култаєва, 2008: с. 128].

Б. Вальденфельс робить спробу вирішити проблему «іншого» через просторову переорієнтацію всього феноменологічного проекту. Спираючись на побудову феноменологічної топографії, «в якій «іншого» слід шукати не в часі (традиції, власній біографії тощо), а в просторі, поруч із собою як трансцендентальну умову досвіду», Б. Вальденфельс пропонує проект інтерсуб'єктивного досвіду «іншого». Його думка про те, що простір слід осмислювати таким чином, щоб він залучав свої та чужі місця для того, щоб звузити чи скасувати відмінність між «своїм» і «чужим», він розкриває «чуже» як конструктивний момент «свого» [Вальденфельс, 2002. c. 159]. Слід зауважити, що «чуже» у Б. Вальденфельса не $\epsilon$ гомогенним, а структурується за рівнями чужості. На думку Б. Вальденфельса, існує три аспекти - місце, володіння та рід, які відрізняють «своє» від «чужого». Він пише: «Чуже, по-перше, це те, що відбувається поза своєю цариною і персоніфікується у формі «чужинця» та «чужинки». Чуже, по-друге, $є$ тим, що належить «іншому..., по-трете, щось чужого роду, яке й вважається чужорідним...» [Вальденфельс, 2002: с. 187]. У такому сенсі «чуже» $\mathrm{\epsilon}$ вагомим чинником процесу самоідентифікації. Але слід сказати, що самоідентифікація може приймати форму негативної ідентифікації, коли зміст «свого» визначається не шляхом відтворення позитивних рис та цінностей свого «Я» або «Ми», а через заперечення «чужого». Як наслідок, чуже ототожнюється $з$ ворожим, яке, в свою чергу, втрачає можливість бути конструктивним чинником i перетворюється на руйнівну силу [Тейлор, 2005: с. 209].

Процес самосприйняття може приймати форму негативної ідентифікації, коли зміст «свого визначається не шляхом відтворення позитивних рис та цінностей свого «Я» або «Ми», а через заперечення 
«чужого». Тому варто не використовувати поняття «чужого», оскільки поняття «іншого» забезпечує можливість пізнання та, як наслідок, профілактики ксенофобії та остракізму. Однак, для того, щоб визначити своє (особистість, культуру, мову, етнос тощо), не існує іншого шляху, ніж як відокремити його від «чужого». Річ у тому, що така виразна самоідентифікація досить часто приводить до радикальної чужості, стає причиною конфліктів, провокує негативне та вороже сприйняття «чужого» [Тейлор, 2005: с. 223].

Соціальна самоідентифікація, яка набуває типових рис негативної ідентифікації, приводить до загострення конфліктів, буллінгу, психологічного тиску на «іншого». «Чужий» - це ворог, а інший - це первинний об'єкт пізнання. Однак, «чужий» може бути й другом. Отже, існують різні стилі чужорідності. На цій думці робить наголос й Б. Вальденфельс, він пише: «у разі «свого» й «чужого» йдеться не просто про два терміни, а про два топоси» [Вальденфельс, 2002: с. 243]. Саме тому, «чуже i своє» можна розглядати як корелянти спільного інтерсуб'єктивного світу комунікації та соціальної дії, але можна представити і як антропологічні можливості, які перегукуються між собою та взаємодоповнюють одне одного.

Варто зауважити, що ксенофобія виникає в суспільстві, що конституюється або окремою людиною, або соціальними групами, як i навчальна група в освітньому середовищі, що носить стійкі ознаки внутрішнього порядку. Позиція щодо «чужого» переходить у ксенофобію, коли це «чуже» вже перевищує градуальні рамки припустимої чужості, коли чужість принаймні у сприйнятті стає ексцентричною, незрозумілою, а відтак - екзотично привабливою або відштовхуючою. Позитивне емоційне ставлення до чужого ще не можна вважати запорукою уникнення ксенофобії, однак може стати основою психопрофілактичних дій остракізму.

Одна й та сама соціальна процедура відтворює широке коло i сприятливих, і несприятливих форм [Элиас, 2001: с. 107]. На думку Н. Еліаса, цивілізаційний процес завжди містить у собі можливість впадання у варварство, адже система самоконтролю, яка віками складається як передумова стратегії виживання людини, може виходити 3 ладу або виявляється занадто слабкою, щоб стримувати «кримінальні енергії» або руйнівні потяги, які стримує індивід. Н. Еліас застерігає: «Автоматично відтворювані страхи, закріплені за певними потягами у ході конфліктів індивідуального процесу цивілізації, за конкретних обставин призводять не до повного згасання окремих потягів, а тільки до їх придушення i регулювання в рамках того, що вважається нормою. Каналізація і трансформація енергії певних потягів можуть знаходити також прояв і в соціально зайвих нав'язливих діях, а також у нахилах i діях, що видаються дивними, але саме вони здатні виступати як види 


\section{Psychology}

діяльності, що приносять індивіду задоволення і $є$ найбільш плідними 3 соціальної точки зору» [Элиас, 2001: c. 145].

Соціокультурні контексти впливають на механізми самоконтролю людини. Ці механізми, в тому числі й такі, як совість і сором, не є суто індивідуальним надбанням людини, а вагомою складовою психогенези людства. Н. Еліас зауважує щодо цього: «У минулому свідомий і несвідомий контроль залишався неповним і мав лазівки для недоцільних, 3 соціальної точки зору, дій. Тепер цей самоконтроль нагадує суцільний льодовий панцир, і питання криється в тому, наскільки він є стабільним i відповідає побудові суспільства. Але через те, що саме в наші дні побудова суспільства $є$ надзвичайно змінюваною, то від індивіда вимагається гнучкість поведінки, за яку змушено сплачується стабільністю» [Элиас, 2001: с. 156].

Сучасні інтеркультурні контексти характеризуються прискореною динамікою, через що «індивідуальний процес цивілізації» значно ускладнюється, даючи мотиви не тільки проявам старих фобій, а й породжуючи нові, це явище демонструють навчальні простори інклюзивного середовища. Для їх розрізнення важливого методологічного значення набуває висновок Н. Еліаса: «Не так вже й важко сказати теоретично, де проходить межа між успішним i неуспішним індивідуальним процесом цивілізації. У першому випадку підсумком усіх страждань і конфліктів є добре пристосований до виконання функцій апарат звичок $\mathrm{i}$ - що не завжди його супроводжує - позитивний баланс задоволення. У другому випадку саморегуляція, яка вимагається суспільством, або досягається за рахунок особистої незадоволеності, або взагалі не досягається, бо не вдається упоратися 3 потягами, а баланс задоволеності виявляється неможливим, бо соціальні настанови і заборони встановлюються не іншими людьми, а самим страждальцем, у душі якого одна інстанція забороняє і карає за те, чого прагне інша» [Элиас, 2001: c. 123]. Трансформація понять «чужого» на «іншого», якого треба пізнати і полюбити, який може бути не тільки конкурентом та супротивником, але й партнером та співрозмовником, $\epsilon$ складним соціально адаптаційним утворенням та потребує системного супроводу в суспільстві.

Оскільки страх перед «чужим» як невідомим лежить в основі ксенофобії і здатний провокувати афективні стани іiі прояву, пізнання причин страхує передумовою терапії від наляканості «чужим». Цей страх через відповідні світоглядні, виховні та ідеологічні настанови трансформується у зацікавленість, що спричинює соціокультурні практики взаємодії і взаємообміну.

Безперечно, страх як психічний стан має безліч градацій і відтінків, обумовлених його соціальним та індивідуальним підгрунтям, але в усякому разі успішною його передумовою конструктивної трансформації $\epsilon$ зіткнення з об'єктом страху. 
Страх є природною реакцією людини. Він так само, як і агресія, забезпечує виживання людини i вписаний у іiі біологічну еволюційну програму. Страх людини відрізняється від страху тварини тим, що він може заміщуватися, переноситися на інші об'єкти, а також здатний контролюватися розумом. Приборкання страху є важливою передумовою антропосоціогенезу.

Так само, як і страх, до антропологічних характеристик людини належить заздрість. Відомий німецький представник культурної антропології Г. Шьок так характеризує людину: «Людина є такою живою істотою, якій притаманна заздрість. Без соціальних стримуючих механізмів люди не змогли б розбудовувати такі складні соціальні системи, які забезпечують функціонування модерних суспільств» [Seitz, 2002: c. 191]. Страх і агресія слугує протилежним завданням. Так, з однієї сторони, вона впливає на розбудову механізмів пристосування, а 3 іншої, - провокує руйнацію, реалізацію деструктивного потенціалу, закладеного в людській природі [Seitz, 2002: c. 194].

Лякати «чужими» чи хворими є елементом самоствореного образу для формування соціального відторгнення та вигнання - остракізації, що виконує активну роль у формуванні соціальних груп за деструктивними інтересами у повсякденності. Соціальні переднастанови в соціумі, таким чином, здатні створювати своєрідні мініміфи [Williams, 2005: c. 51]. Без мініміфів ксенофобія не може існувати у просторі повсякденності, так само, як у іiі ідеологізованих варіантах вона потребує гранднаративу про походження, націю, релігійність, приналежність до певної спільноти тощо. Мініміфи, що забезпечують виключення/ неприйняття, $\epsilon$ дуже небезпечними, адже вони формуються на рівні суспільної психології та намагаються викликати афективну тріаду до самого способу існування «чужого», що торкається побуту, способу задоволення елементарних потреб, самовираження тощо, i, як наслідок, відбувається формування умов для забезпечення остракізації, вигнання «чужого» як загрози для безпечного існування групи. У мініміфах широко застосовуються спотворені інтерпретації невербальної комунікації, які можуть поширюватися до «чужого», що загрожує існуванню груп, які провокують такі чутки. Так, досить часто при включенні дитини в новий або ж інклюзивний простір виникають чутки або мініміфи, що від нього чи неї можна отримати хворобу чи стати таким же хворим, які відповідно сприяють остракізації даної особи.

Спростування чуток навіть у малому соціальному колективі $\epsilon$ своєрідним контрнаступом, спрямованим проти змісту i настроїв, які починають домінувати серед певних мінісоціальних груп. Але небезпека чуток або недостатньої інформації, особливо ксенофобного характеру (неприйняття), полягає у тому, що вони ніколи не спростовуються повністю. Соціальна психологія закріплює відповідні змістовні блоки на емоційні переживання. Це забезпечує за сприятливих обставин досить 


\section{Psychology}

швидке відтворення мініміфів ксенофобного змісту, що призводить до процесу остракізації [Williams, 2005: c. 49]. Плітки зосереджують свою увагу на чомусь «утаємниченому», намагаючись на рівні повсякденної комунікації зробити це утаємничене прозорим i доступним соціокультурному оточенню, тому можливо достатній рівень про «інакшість» стане досить потужним методом профілактики остракізму та спричинить мінімізацію перестороги та страху щодо людини, яка $\epsilon$ остракізованою в соціальному просторі. Ми передбачаємо, що прозорість інформації про «чужого», «іншого» або ж дитину з особливими потребами має дати сама дитина в начальному просторі, педагог, який включає дитину в соціальний простір, психолог же, забезпечуючи спільні згуртовуючі дії, також позитивно впливатиме на зниження загального статусу напруги та остракізації.

Так, психологічні засади супроводу мають стати джерелом дружелюбності та толерантності до «чужого», «іншого» i ïx треба підтримувати і розбудовувати, бо вони є здобутком продуктивної історії суспільства і профілактики ксенофобії та остаркізму.

Сподівання щодо суспільноперетворюючої спроможності культури свободи та толерантності, заснованої на антропологічних і моральноетичних засадах, не є новими. Але заклики до створення і підтримки атмосфери дружелюбності, вдячності, вимога прощати і ділитися не лише нагадують про це соціальне надбання, а й спрямовані на його функціоналізацію та адаптацію до тих ситуацій психологічної підтримки особистості під час кризу свого буття.

Характеризуючи освітні стратегії в толерантному просторі сучасності, не можна пройти повз таких соціальних формоутворень, якими є стилі життя та моделі життєтворчості. Адже освітні стратегії розробляються не у вакуумі, а визначаються різними соціальними контекстами. Висуваючи серед цих контекстів на передній план стилізацію життєтворчості, треба виділити не стільки загальний, об'єктивний момент освітніх стратегій, а й їхню людиновимірність, отже певною мірою поєднати макро- і мікросоціологічне наближення до такого специфічного різновиду духовного процесу, яким $є$ освіта й виховання. Адже формування соціальної групи в системі соціальної життєтворчості стає головним завданням мінімізації остракізації в суспільстві.

Висновки. У рамках філософського розгляду феномену ксенофобіiі, поняття «чужого», «іншого» виступає підгрунтям суспільної ідентифікації та категоризації. Соціальна самоідентифікація, що набуває типових рис негативної ідентифікації, приводить до загострення конфліктів, буллінгу, психологічного тиску на «іншого». В основі лежить полярна категоризація: «чужий - це ворог, а «інший» - це первинний об’єкт пізнання.

У такому сенсі «чуже» виступає вагомим чинником процесу самоідентифікації. Але слід сказати, що самоідентифікація може приймати форму негативної ідентифікації, коли зміст «свого» визначається не 
шляхом відтворення позитивних рис та цінностей свого «Я» або «Ми», а через заперечення «чужого». Як наслідок, чуже ототожнюється з ворожим, яке, в свою чергу, втрачає можливість бути конструктивним чинником та перетворюється на руйнівну силу.

У процесі формування толерантної свідомості важливо не використовувати поняття «чужого», оскільки поняття «іншого» забезпечує можливість пізнання та, як наслідок, профілактики ототожнення 3 ворожим, яке, в свою чергу, не втрачає можливості бути конструктивним чинником і перетворюється на рушійну силу пізнання та, як наслідок, прийняття.

Поняття остракізму є актом чи системою ігнорування, виключення окремих осіб. Незважаючи на відсутність словесних принижень і фізичних нападів, його прояви є болючими та загрожують психологічним потребам (приналежності, почуття власної гідності, контролю та осмисленості існування), і це викликає різні психічні, афективні, когнітивні й поведінкові реакції.

У рамках профілактики остракізму ми передбачаємо, що прозорість інформації про дитину має дати сама дитина, а педагог, який включає дитину в соціальний простір, і психолог, забезпечуючи спільні згуртовуючі дії, також позитивно впливатимуть на зниження загального статусу напруги та остракізації.

Перетворення «чужого» на «іншого», якого треба пізнати i полюбити, який може бути не тільки конкурентом та супротивником, але й партнером та співрозмовником, такий процес $\epsilon$ складним соціально адаптаційним утворенням та потребує системного супроводу в суспільстві.

\section{ЛІТЕРАТУРА}

Абраменкова, 2000 - Абраменкова В. Социальная психология детства: развитие отношений ребенка в детской субкультуре. Воронеж : НПО «МОДЭК», 2000. 416 с.

Вальденфельс, 2002 - Вальденфельс Б. Топографія Чужого: студії до феноменології Чужого / Бернгард Вальденфельс; пер. 3 нім. Київ : ППС, 2002. 206 с.

Култаєва, 2008 - Култаєва М., Навроцький О., Шеремет І. Європейська теоретична соціологія XX-ХХІ століття. Харків : ХНУ імені В.Н. Каразіна, 2008. 328 с.

Тейлор, 2005 - Тейлор Ч. Джерела себе: творення новочасової ідентичності : пер. $з$ англ. Київ : Дух і літера, 2005. 696 с.

Элиас, 2001 - Элиас Н. О процессе цивилизации. Социогенетические и психогенетические исследования. Т. 2. Изменения в обществе. Проект теории цивилизации. Социогенетические и психогенетические исследования / пер. с нем. А. М. Руткевич. Москва, Санкт-Петербург : Университетская книга, 2001. 382 с.

Glatzer, 1992 - Glatzer W. Lebensqualitaet und subjektives Wohlbefinden. Ergebnisse sozialwissenschaftlicher Untersuchungen, 1992. 248 p.

Seitz, 2002 - Seitz K. Bildung in der Weltgesellschaft. Gesellschaftstheoretische Grundlagen Globalen Lernens. 2002. 298 p.

Williams, 2001 - Williams K. Ostracism: The Power of Silence. New York : Guilford Press, 2001. $282 \mathrm{p}$. 


\section{Psychology}

\section{REFERENCES}

Abramenkova, 2000 - Abramenkova V. Sotsyalnaia psykholohyia detstva: razvytye otnoshenyi rebenka $\mathrm{v}$ detskoi subkulture. Voronezh : NPO «MODEK», 2000. $416 \mathrm{~s}$.

Valdenfels, 2002 - Valdenfels B. Topohrafiia Chuzhoho: studii do fenomenolohii Chuzhoho / Bernhard Valdenfels; per. z nim. Kyiv: PPS, 2002. 206 s.

Kultaieva, 2008 - Kultaieva M., Navrotskyi O., Sheremet I. Yevropeiska teoretychna sotsiolohiia KhKh-KhKhI stolittia. Kharkiv : KhNU imeni V.N. Karazina, 2008. 328 s.

Teilor, 2005 - Teilor Ch. Dzherela sebe: tvorennia novochasovoi identychnosti : per. z anhl. K. : Dukh i litera, 2005. $696 \mathrm{~s}$.

Elyas, 2001 - Elyas N. O protsesse tsyvylyzatsyy. Sotsyohenetycheskye y psykhohenetycheskye yssletovanyiaiu. T.2 Yzmenenyia v obshchestve. Proekt teoryy tsyvylyzatsyy. Sotsyohenetycheskye y psykhohenetycheskye yssledovanyia / Per. s nem. A. M. Rutkevych. M., Spb: Unyversytetskaia knyha, 2001. 382 s.

УДК 316:159.9.376

DOI 10.31470/2308-5126-2019-42-1-130-137

Оксана Олійник, кандидат психологічних наук, дочент, дочент кафедри психології

Київського начіонального університету культури і мистецтв
Oksana Oliinyk, PhD (Psychology), Associate

Professor, Associate Professor of the

Department Psychology, Kyiv National University of Culture and Arts.

E-mail: okleons777@gmail.com

ORCID 0000-0002-3255-9170

\section{СОЦІАЛЬНО-ПСИХОЛОГІЧНІ ОСОБЛИВОСТІ ПРЕВЕНЦІЇ ДЕВІАНТНОЇ ПОВЕДІНКИ ОСОБИСТОСТІ}

Проаналізовано види і форми прояву девіантної поведінки, визначено роль дозвілля у ї попередженні; виокремлено основні чинники, які обумовлюють девіацію зростаючої особистості; виділено основні напрямки профілактики девіантних форм поведінки. Застосовано як методологію дослідження теоретичні методи (аналіз соиіально-психологічної, педагогічної, культурологічної літератури; систематизація наукової інформаціі) та приниипи (активності, детермінізму, системного підходу). Виділено та проаналізовано чинники, цчо зумовлюють девіантну поведінку дітей і підлітків, охарактеризовано наслідки їхнього впливу на зростаючу особистість та обтрунтовано систему комплексної профілактики девіації. Уточнено та поглиблено уявлення про сочіальні чинники виникнення девіантної поведінки; розроблено систему профілактичної роботи щуодо попередження видів і форм прояву девіації, зокрема медіа-адикиіі як сучасної та найбільш розповсюдженої ї̈ форми; обтрунтовано доцільність реалізачіі профілактичних заходів у сфері дозвілля зростаючої особистості. Зроблено висновок, щзо профілактика девіацій дітей та підлітків є найбільш ефективною саме у сфері дозвілля. Превенція девіантної поведінки на даних вікових етапах має бути комплексною $і$ охоплювати роботу з колом однолітків, сім'єю, освітнім та культурно-дозвіллєвим середовищем зростаючої особистості. Відповідно, дозвіллєва діяльність дітей та підлітків має бути спрямована на зменшення негативного впливу на них засобів масової інформації, обмеження неконтрольованого часу $і$ неорганізованого дозвілля, на забезпечення доступності до закладів культури; сприяти самореалізації, розвитку особистісних якостей та властивостей.

Ключові слова: девіантна поведінка, види девіантної поведінки, форми девіантної поведінки, чинники девіації, адикиія, превениія, дозвілля, особистість.

The research deals with analysis of kinds and forms of manifestation of deviant behavior, place determination of leisure in its prediction, isolation of the main factors which specify deviation of growing person, determination of the main directions of prevention of deviant forms of behavior. Methodology of the research lies in implementation of theoretical methods (analysis of social and 